\title{
PENGARUH EKONOMI KELUARGA TERHADAP PUTUSNYA SEKOLAH ANAK
}

\author{
Muhammad Yusuf \\ Economic Education Program, Faculty of Economics, State University Malang \\ ucupunirow@gmail.com
}

\begin{abstract}
This study aims to determine the factors causing children to drop out of school and Know the impact of children who dropped out of school and to Know the right steps to overcome the problem of school dropouts in the Village District Karangagung Palang. Data collection methods used are interviews and retrieve data from relevant parties. Methods Data analysis was done by grouping the results of interview factors of drop out children to three factors, namely economic factors, environmental factors, personal factors. Based on the data collected, it was found that the factors causing drop out were as follows: economic factors, environmental factors, personal factors.
\end{abstract}

Keywords: Family Economy, Drop Out

History of Article:

Received: (10 June 2017), Accepted : (19 September 2017), Publised: (15 October 2017)

\section{Citation:}

Muhammad Yusuf (2017) Pengaruh Ekonomi Keluarga Terhadap Putusnya Sekolah Anak [The Effect of Family Economy to school dropout of children]

Jurnal Pendidikan Ekonomi, 10(2), 89-95.

(C) Universitas Negeri Malang 


\section{PENDAHULUAN}

Pendidikan merupakan hal yang terpenting dalam kehidupan kita, ini berarti setiap manusia berhak mendapat dan berharap untuk selalu berkembang dalam pendidikan. Hal ini sejalan dengan dengan tujuan pendidikan Nasional berdasarkan UU RI No. 20 tahun 2003 tentang Sistem Pendidikan Nasional, yaitu Pendidikan Nasional bertujuan untuk berkembangnya potensi peserta didik agar menjadi manusia yang beriman dan bertaqwa kepada Tuhan Yang Maha Esa, berakhlak mulia, sehat, berilmu, cakap, kreatif, mandiri dan menjadi warga Negara yang demokratis serta bertanggung jawab.

Pendidikan secara umum mempunyai arti suatu proses kehidupan dalam mengembangkan diri tiap individu untuk dapat hidup dan melangsungkan kehidupan. Sehingga menjadi seorang yang terdidik itu sangat penting, untuk menjadi seseorang yang terdidik maka harus diawali dengan belajar.

Belajar dilakukan oleh setiap orang dari awal-awal kehidupan, seperti belajar merangkak dan belajar berjalan serta belajar berbicara. Ini merupakan proses pembelajaran awal yang terjadi, dialami dan dilakukan di lingkungan keluarga. Ini akan terus berlanjut sampai seorang anak memiliki pola pikir yang baik. Setelah pemikiran anak berkembang, maka anak akan mulai menerapkan didikan yang didapatkannya dari keluarga yang diberikan oleh ayah, ibu dan kakak-kakaknya. Tidak semua ilmu pengetahuan yang bisa diberikan oleh keluarga kepada anaknya.

Anak membutuhkan ilmu pengetahuan yang lebih untuk bisa menjalani kehidupan dengan baik kedepannya. Mengingat pentingnya ilmu pengetahuan dan keterbatasan pihak keluarga dalam memberikan ilmu pengetahuan, maka para orang tua melanjutkan pendidikan anaknya dari pendidikan non formal kepada pendidikan formal dengan memasukkan anaknya ke dalam lembaga pendidikan formal seperti sekolah. Pendidikan formal merupakan hal yang terpenting untuk menghasilkan masyarakat yang memiliki produktifitas yang tinggi. Namun pada hakekatnya pendidikan tidak bisa lepas dari masalah ekonomi keluarga, baik secara langsung mupun secaratidak langsung.

Di Desa Karangagung Kecamatan Palang, tidak semua anak bersekolah, tetapi ada juga yang tidak sekolah/ putus sekolah. Anak yang putus sekolah adalah anak yang harus meninggalkan proses dan aktivitas pendidikan formal mereka. Ini terjadi bukan tanpa sebab, tentunya ada alasan-alasan dan faktor-faktor tertentu yang melatar belakanginnya. Putus sekolah adalah masalah yang sangat amat penting untuk dibicarakan dan dicari jalan solusinya. Permasalahannya putus sekolah diIndonesia bukan masalah kecil. Sebagaimana yang dijelaskan oleh Darmaningtyas (2003), fenomena putus sekolah adalah suatu keadaan terhentinya aktivitas pendidikan pada anak-anak usia sekolah, baik itu pendidikan formal maupun pendidikan informal sebelum mendapatkan pengetahuan yang cukup untuk bertahan hidup dalam masyarakat.

Sebagaimana kita ketahui bersama, jumlah anak yang putus sekolah di Indonesia dewasa ini angkanya tidak puluhan orang tetapi sudah mencapai ribuan orang, ini tidak angka yang kecil. Dalam Penyelesaian masalah anak putus sekolah ini, bukanlah tanggung jawab satu, dua orang atau suatu lembaga saja. Tetapi semua orang dan semua lembaga bertanggung jawab pada masalah ini. Jika permasalahan anak putus sekolah ini tidak ditangani dengan cepat dan tepat, maka akan berdampak buruk bagi perekonomian Indonesia dan sosial bangsapun akan terganggu. 
Dengan banyaknya anak putus sekolah yang semakin bertambah akan berdampak kepada pengangguran, karena kemampuan yang dimiliki anak putus sekolah tersebut tidak mencukupi untuk mengisi lapangan pekerjaan yang semakin canggih dan membutuhkan keahlian-keahlian khusus. Maka, angka pengangguranpun akan bertambah. Jadi, bagaimana Indonesia bisa dan mampu bersaing dengan Negara- negara maju, sedangkan kualitas Sumber Daya Manusia (SDM) Indonesia masih jauh ketinggalan dari Negara-negara maju.

Perlu diketahui juga, anak-anak yang putus sekolah yang akhirnya menganggur akan semakin didesak oleh kebutuhan hidup yang terus meningkat, yang akan mendorong anak untuk bertindak kriminalitas seperti pencurian, perampokan, bahkan sampai pembunuhan dan lain-lain sebagainya. Yang bisa membuat masyarakat menjadi semakin terganggu dan ketentraman yang telah terjalin ditengah-tengah masyarakat akan semakin hilang. Berdasarkan latar belakang diatas maka rumusan masalah yang dibuat yaitu faktor-faktor apa saja yang menyebabkan anak-anak di Desa Karangagung putus sekolah. Tujuan dari penelitian ini yaitu untuk mengetahui faktor- faktor yang mempengaruhi putus sekolahnya anak.

\section{METODE PENELITIAN}

Jenis penelitian ini adalah penelitian kualitatif menggunakan metode studi kasus penelitian kualitatif ditujukan untuk memahami fenomena-fenomena sosial dari sudut perspektif partisipan yang diajak berwawancara, diobservasi, diminta memberikan data, pendapat, pemikiran dan persepsinya. Penelitian Kualitatif ini menggunakan desain studi kasus. Strategi penelitian merupakan cara untuk memperoleh atau mengumpulkan data-data yang menjadi objek, subjek, variabel serta masalah yang diteliti agar data yang diperoleh lebih terarah ketujuan yang hendak dicapai. Subjek dalam penelitian ini yaitu anak- anak putus sekolah, orang tua anak yang memiliki anak putus sekolah, sedangkan objek dalam penelitian ini yaitu faktor- faktor yang menyebabkan anak putus sekolah. Teknik pengumpulan data yang digunakan dalam penelitian ini, meliputi metode wawancara dan observasi. Dan teknik analisis data dilakukan dengan cara mengelompokkan hasil wawancara faktor anak putus sekolah kepada tiga faktor.

\section{HASIL DAN PEMBAHASAN}

Pendidikan merupakan bagian terpenting dalam kehidupan manusia yang sekaligus dapat membedakan antara manusia dan hewan. Hewan juga belajar tapi lebih ditentukan oleh instinknya. Sedangkan bagi manusia belajar berarti rangkaian kegiatan menuju pendewasaan, guna mencapai kehidupan yang lebih kita kenal dengan istilah sekolah. Sekolah adalah bagian dari suatu aktivitas yang sadar akan tujuan. Sekolah dalam hal ini pendidikan menempati posisi yang sangat sentral dan strategis dalam membangun kehidupan secara tepat dan terhormat.

Pendidikan pada hakekatnya merupakan suatu keharusan bagi setiap manusia secara keseluruhan. Setiap manusia berhak mendapatkan atau memperoleh pendidikan, baik secara formal, informal maupun non formal. Sehingga nantinya ia akan memiliki mental, akhlak, moral dan fisik yang kuat serta menjadi manusia yang berbudaya tinggi dalam melaksanakan tugas, kewajiban dan tanggung jawabnya dalam masyarakat. Hal ini sesuai dengan pasal 31 ayat 1 UUD 1945, yang menyatakan bahwa: " Tiap-tiap warga Negara berhak mendapat 
pengajaran", (Idi, 2011: p. 161)

Namun jika kita lihat dari kenyataan dalam pelaksanaannya khususnya di Desa Karangagung Berdasarkan keterangan dari salah satu guru di SMA M 2 Palang, Ibu Kuliah,S.Pd banyak anak-anak remaja yang putus sekolah, dengan berbagai faktor penyebabnya, yaitu: faktor Ekonomi, faktor Lingkungan, dan Faktor Pribadi. Hal ini sesuai dengan hasil penelitian Dewi, dkk (2014) bahwa ada enam faktor penyebab anak putus sekolah usia Pendidikan dasar di Kecamatan Gerokgak Tahun 2012/2013, antara lain: 1) faktor ekonomi; 2) faktor perhatian orang tua; 3) fasilitas pembelajaran; 4) minat anak untuk sekolah; 5) budaya dan 6) faktor lokasi sekolah.

Berdasarkan hasil penelitian ini, faktor penyebab anak-anak remaja yang putus sekolah antara lain:

\section{Faktor Ekonomi}

Berdasarkan keterangan dari pihak terkait, diketahuilah bahwa profesi orang tua siswa dan siswi yang bersekolah di Desa karangagung terdiri dari profesi Nelayan, Pedagang, Pegawai Negeri Sipil (PNS). Berikut persentase profesi orang tua siswa dan siswi yang bersekolah di Karangagung yang sekaligus menjadi masyara-kat Desa Karangagung yang memiliki luas wilayah 69,8375 Ha, yang berpenduduk sebanyak 10.145 Jiwa yang terdiri dari 5.121 Jiwa (Orang Lakilaki) dan 5.024 Jiwa (Orang perempuan), dengan Kepala Keluarga sebanyak 2.758 Jiwa dan anggota keluarga sebanyak 7.387 Jiwa. Yang mayoritas profesinya adalah nelayan.

\begin{tabular}{|l|c|c|}
\hline No & Profesi & Persentasi \\
\hline 1. & Nelayan & $70 \%$ \\
\hline 2. & PNS & $25 \%$ \\
\hline 3. & Pedagang & $5 \%$ \\
\hline
\end{tabular}

Dilihat dari tabel diatas diketahui mata pencaharian masyarakat yang ada di Desa Karangagung adalah mayoritas nelayan. Dalam pemenuhan kebutuhan seharihari dianggap kurang terutama dalam biaya pendidikan.

Hal ini mengakibatkan banyak anak tidak melanjutkan kegiatan belajar mengajar mereka sebagai siswa demi membantu kedua orang tua mereka. Dilihat dari profesi orang tua sebagai PNS banyak anak yang orang tuanya bekerja sebagai pegawai juga tidak menyelesaikan pendidikan mereka.

\section{Faktor Lingkungan}

Pendidikan yang diterima seorang anak sebelum memasuki pendidikan formal adalah pendidikan non formal yang bersumber dari keluarga dan lingkungan masyarakat, disinilah awal pembentukan karakter dan kepribadian anak. Namun, tidak semua lingkungan yang mendukung pendidikan anak. Ada lingkungan yang memberi pengaruh negatif kepada anak yang mengganggu proses pembelajaran anak di sekolah. Pengaruh negatif dari lingkungan banyak yang menyebabkan anak putus sekolah. Lingkungan tersebut adalah:

a) Lingkungan Keluarga

Keluarga merupakan ling-kungan yang pertama kali ditemui oleh setiap individu. Semenjak seorang anak dilahirkan hingga mencapai usia sekolah, keluargalah yang paling sering ditemui. Didalam keluarga inilah pembentukan karakter dan kepribadian seorang anak. Karakter yang telah ada tersebut dibawa 
seorang anak ke lingkungan luar, sepeti lingkungan masyarakat, termasuk lembaga pendidikan. Pada keluarga yang kurang harmonis atau tidak harmonis, anak tidak bisa tumbuh dan berkembang secara baik. Baik secara fisik maupun secara psikologis. Sehingga anak tumbuh menjadi anak yang nakal. disekolah, anak yang tumbuh dilingkungan keluarga yang tidak baik, mereka sering melanggar aturan dan tidak bisa menerima pelajaran dengan baik karena batin dan pemikiran mereka terganggu oleh persoalan dirumah.

b) Lingkungan Teman Pergaulan Selain lingkungan keluarga.

Lingkungan teman per-gaulan juga membentuk karakter dan kepribadian dari anak. Lingkungan teman pergaulan ini juga bisa membuat anak putus sekolah. Dikalangan siswi sebahagian putus sekolah karena dipengaruhi oleh pacarnya, karena pacarnya mengajak siswi tersebut untuk menikah. Berbeda dikalangan siswa walaupun, telah dipriori-taskan untuk bersekolah oleh orang tuanya, siswa tetap tidak mengikuti proses belajar rmengajar dengan baik dan sering melanggar aturan, ini disebabkan karena pengaruh teman dilua sekolah yang tidak bersekolah. Bagi siswa ditingkat SMA/ sederajat, siswa yang putus sekolah karena teman pergaulan ini yaitu karena siswa tersebut berteman dengan anak yang tidak bersekolah dan terbawa oleh kebiasaan temannya tersebut seperti merokok, minum-minuman keras, berjudi dan ngumpul-ngumpul sampai larut malam bahkan sampai dini hari. Dengan terbawa oleh kebiasaan teman yang tidak bersekolah tersebut akan membuat siswa tida bisa mengikuti pelajaran disekolah dengan baik karena rasa ngantuk akibat kurang tidur dan juga malas untuk sekolah. Dan apabila kebiasaan merokok, minim-minuman keras, dan berjudi itu diketahui pihak sekolah tentunya akan membuat siswa itu dikeluarkan dari sekolah dan putus sekolahpun terjadi.

3.Faktor Pribadi

Manusia adalah makhluk bebas yang memiliki hak dan kewajiban. Melanjutkan pendidikan atau berhenti adalah pilihan. Walaupun perekonomian orang tua bisa membiayai biaya sekolah, namun jika keinginan untuk melanjutkan sekolah tidak ada, maka anak tersebut tetap akan mengalami putus sekolah. Seseorang yang keluar dari sekolah atau putus sekolah ada yang didasari keinginannya sendiri.

Memilih putus sekolah tentunya ada alasan. Secara garis besar anak memilih putus sekolah karena:

a) Tidak ingin menyusahkan orang tua

Melihat perekonomian orang tua yang berada digaris menengah kebawah membuat suatu pemikiran dikalangan siswa siswi bahwa "lebih baik berhenti sekolah dan membantu orang tua, kalaupun sekolah belum tentu akan berhasil" dengan pemikiran seperti ini seorang anak memilih untuk putus sekolah dan lebih memilih bekerja. Rasa kasihan timbul dari hati siswa siswi melihat kondisi orang yang semakin tua, palagi kalau orang tua yang tidak lengkap, baik berpisah karena meninggal maupun berpisah karena cerai.

b) Rasa Malu

Menurut teori psikogenesis konflik batin mempengaruhi kepribadian anak. Sebagaimana kita ketahui kemampuan seseorang dalam belajar dan menerima pelajaran tidaksama. Anak yang kurang dalam menerima pelajran dan sering tidak naik kelas. Memutuskan untuk putus sekolah karena malu belajar disekolah. Selain malu belajar dengan anak yang seharusnya adik kelasnya, dia juga malu dengan 
teman-temannya yang telah naik kelas.

c) Kesadaran akan kebutuhan belajar anak kurang

Ada anak yang berfikiran bahwa belajar itu hanya buang- buang waktu yang tidak menghasilkan apa-apa. Bisa membaca dan menulis saja sudah cukup.Pemikiran anak seperi itu merupakan pemikiran zaman dahulu bahkan pemikiran diera globalisasi. Namun, ini masih ada dikalangan pelajar.

d) Tidak merasakan nikmatnya sekolah

Banyak para pelajar yang tidak merasakan nikmatnya sekolah dan lebih cendrung kepada bermain-main. Ini terjadi karena disekolah dia tidak bisa berbuat banyak, karena kemampuan berfikir yang kurang dan malas mengikuti kegiatan sekolah seperti organisasi. Yang membuat mereka tidak dengarkan pelajaran pelajaran dan pulang. Ini membuat mereka jenuh dan memilih untuk putus sekolah. Dan juga disebabkan karena memasuki suatu sekolah atas paksaan orangtua.

e) Telah merasakan nikmatnya mendapat uang sendiri Untuk membantu perekonomian keluarga.

Banyak anak sekolah yang bekerja sampingan, dari kerjanya tadi anak memperoleh hasil yaitu uang. Dengan menerima hasil ini, anak belajar "untuk apa sekolah lagi, saya sudah bisa mendapatkan uang sendiri" sehingga anak lebih memilih untuk bekerja dan putus asa. Setelah putus sekolah anak tersebut melanjutkan pekerjaan yang telah dijalani sewaktu dalam jenjang pendidikan.

Dari beberapa faktor yang telah disebutkan diatas adapun dampak yang ditimbulkan dariputus sekolahnya anak yaitu:

a. Dari pihak keluarga

Dari segi positif

- Dapat membantu perekonomian keluarga

- Mengurangi beban orang tua

Dari segi negatif

- Semakin membuat resah orang tua karena kelakuan semakin bebas

- Membuat malu orang tua dan keluarga karena putus sekolah akibat pergaulan bebas

b. Dari Masyarakat

Dampak positif Dapat membantu

Pekerjaan bagi masyarakat yang membutuhkan sedangkan Dampak negatif Membuat keresahan di masyarakat karena anak yang putus sekolah berbuat tindakan amoral. Seperti minum-minuman keras, berjudi, tawuran dan pembunuhan akibat tekanan kebutuhan yang semakin meningkat.

c. Dari Pemerintahan

Dampak negatif Membuat angka pengangguran semakin meningkat, Kriminalitas semakin meningkat, Pengeluaran pemerintah dalam hal biaya sosial anak akan bertambah, seperti yang berkaitan dengan perawatan psikologis, peningkatan kualitas pengamanan wilayah dan peningkatan volume proses peradilan 


\section{KESIMPULAN}

Berdasarkan penelitian yang dilakukan diperoleh hasil faktor penyebab putus sekolah sebagai berikut: 1) faktor ekonomi; 2) faktor lingkungan; 3) faktor pribadi antara lain: tidak ingin menyusahkan orang tua, malu, kesadaran akan kebutuhan belajar anak kurang, telah merasakan nikmatnya mendapat uang sendiri

\section{DAFTAR PUSTAKA}

Creswell, John W(2015). Penelitian kualitatif \& Desain Riset Memimilih diantara lima Pendekatan. Yogyakarta:Pustaka Pelajar.

Darmaningtyas (2003) Pendidikan yang Memiskinkan. Jogjakarta: Galang Press

Depdiknas (2003) Undang-undang RI No.20 tahun 2003.tentang Sistem Pendidikan Nasional, Jakarta: Sinar Grafika.

Dewi, Ni Ayu Krisna, Anjuman Zukhri \& I Ketut Dunia (2014) Analisis faktorfaktor penyebab anak putus sekolah Usia pendidikan dasar di kecamatan gerokgak tahun 2012/2013. Jurnal Pendidikan Ekonomi Undiksha, 4 (1), 1-12

Idris, Z. (1982) Dasar-dasar Kependidikan. Bandung: Angkasa

Idi, Abdullah H dan Safarina HD.(2011) Sosiologi Pendidikan, Jakarta. PT Raja Grapindo Perseda.

Slameto.(2010) Belajar dan Faktor- FaktorYangMempengaruhinya. Jakarta:

Rineka 